\title{
Sap Flow Study on Two Different Diameter Sizes of Tectona grandis
}

(Kajian Resapan Sap ke atas Saiz Diameter Berbeza bagi Tectona grandis)

\author{
MARRYANNA LION*, SITI-AISAH SHAMSUDDIN \& WAN MOHD SHUKRI WAN AHMAD
}

\begin{abstract}
Sap flow pattern of Tectona grandis planted at lowland forest assessed. This study aimed to determine the sap movement of two different diameter sizes T. grandis. Two sizes selected were 16 and $38 \mathrm{~cm}$ in diameter at breast height (dbh). Sap flow meter (SFM) used to assess the sap velocity rates at the interval of 30 min within 24 h for 15 days. Diurnal sap flow of T. grandis shows that mean velocity is high during day time compared night time. Small diameter has high sap flow compared to that of bigger diameter. A flow rates was high at the inner layer and less at outer layer for smaller tree. The variation was vice versa when the tree was getting bigger. Variations in sap flow of T. grandis characterized by several environmental factors. It was found that size contribute in the differed sap flow of $\mathrm{T}$. grandis.
\end{abstract}

Keywords: Diameter sizes; lowland forest; sap flow; Tectona grandis

\section{ABSTRAK}

Kajian telah dilakukan terhadap corak aliran sap bagi Tectona grandis yang ditanam di hutan tanah rendah. Tujuan kajian ini ialah untuk menentukan pergerakan sap bagi dua diameter dirian pokok T. grandis yang berbeza. Dua saiz yang dipilih adalah 16 dan $38 \mathrm{~cm}$ diameter pada paras dada (ppd). Alat pengesan aliran sap (Sap flow meter - SFM) digunakan untuk menilai kadar halaju sap pada selang 30 minit dalam tempoh 24 jam selama 15 hari. Purata aliran siang malam oleh $\mathrm{T}$. grandis menunjukkan bahawa halaju purata adalah tinggi pada waktu siang berbanding waktu malam. Saiz diameter yang kecil mempunyai aliran sap yang lebih tinggi berbanding dengan diameter yang besar. Bagi saiz diameter pokok yang kecil, kadar aliran sap adalah tinggi di lapisan dalaman berbanding lapisan luar. Corak perbezaan ini akan menjadi sebaliknya apabila saiz pokok tersebut semakin besar. Variasi dalam aliran sap T. grandis dicirikan oleh beberapa faktor persekitaran. Penemuan mendapati bahawa saiz diameter pokok menyumbang kepada perbezaan aliran sap pada $\mathrm{T}$. grandis.

Kata kunci: Aliran sap; hutan tanah rendah; saiz diameter; Tectona grandis

\section{INTRODUCTION}

The use of water by plants is one of the important factors for the plant to grow and to process food. Water use efficiency is the photosynthesis production rate at which water evaporates into the air through transpiration. Usually trees use or lose water by two processes. These includes of root water uptakes from the soil and the interception of water by the surfaces of leaves, branches and trunks during rainfall (Nisbet 2005). Sap is simply referred as a fluid transported from the root towards the leaves in the plant through xylem. Data from sap flow study can be translated as a tree water use when combined with other function such as soil moisture and transpiration. Sap flux density (SFD) is a term used to denote volume of water moving through the stem vessels per square sapwood area per unit time expressed in units of $\mathrm{mL} /\left(\mathrm{cm}^{2} \mathrm{~h}\right)$.

The study on sap flow and water use has been widely conducted in temperate country but less has been done in Malaysia. Studies focuses on techniques and variations in water use in response to environment condition. Smith and Allen (1996) studied the method of measuring sap flow in plant stems. They focus on the four methods namely stem heat balance, trunk heat balance, heat-pulse method and thermal dissipation technique. All of these methods use heat as a tracer for sap movement, but fundamentally different in their operating principles. Based on review by Cermak and Kucera (1981); Diawara et al. (1991), Olbrich (1991) and Weibel and de Vos (1994), each of the four methods of measuring sap flow is reported to be accurate to within $10 \%$. Finding by Cienciala et al. (1997), Du and Yang (1995) and Lagergren and Lindorth (2002) suggested that sapflow or transpiration of trees may be closely related to plant hydraulic variables and environmental factors especially soil types. According to Scott (2005), there are evidence indicates that plantation forestry may have specific hydrological characteristics that are related to the fast rate of growth of the species used, with corresponding high water consumption and the short rotation period of the forest stands, which does not permit the catchment water balance to achieve hydrological stability as the forest cover ages. Therefore, specific study on the water consumption by particular 
species is important to facilitate the better species selection.

This study aimed to collect baseline data on water movement of different tree size in Tectona grandis under the same environmental conditions. Tectona grandis was selected in this study based on its importance under the Malaysian plantation programme and availability in FRIM Research Station. This paper reports the study of sap flow dependence on climatic parameters as well. Generally, this study emphasize on hydrological character of the tree water use.

\section{MATERIALS \& METHODS}

A field study was conducted at FRIM's Research Station in Mata Ayer, Perlis. It is located in compartment 23 of the Mata Ayer Forest Reserve, Jalan Padang Besar, Perlis, Malaysia. The forest reserve covers an area of 455 ha.
Generally the topography is flat and drained by the Sungai Chucor. The elevation of the area is $30 \mathrm{~m}$ above sea level (Figure 1).

Sap flow in Tectona grandis was measured using sap flow sensor (SFM) with heat ratio method (HRM). The SFM sensor includes of three probes that were downstream probe, heater and upstream probe. The length of each probe is $3.5 \mathrm{~cm}$. The SFM powered with internal $4 \mathrm{~V} 1$ Amp DC Lithium polymer batteries that is used to operate the instrument. A $12 \mathrm{~V}$ external battery supplies used for two weeks measurement at $30 \mathrm{~min}$ interval. Prior to the measurement, apparatus and equipment for establishment of SFM sensor was prepared. This includes the SFM sensor, drill, drill pin guide and methyl orange, followed by preparing tiny holes for sensor insertion. Drill pin guide use to ensure that the holes prepared diametrical or straight. Sensors inserted according to the sequences which followed by downstream pin at the top position, heater

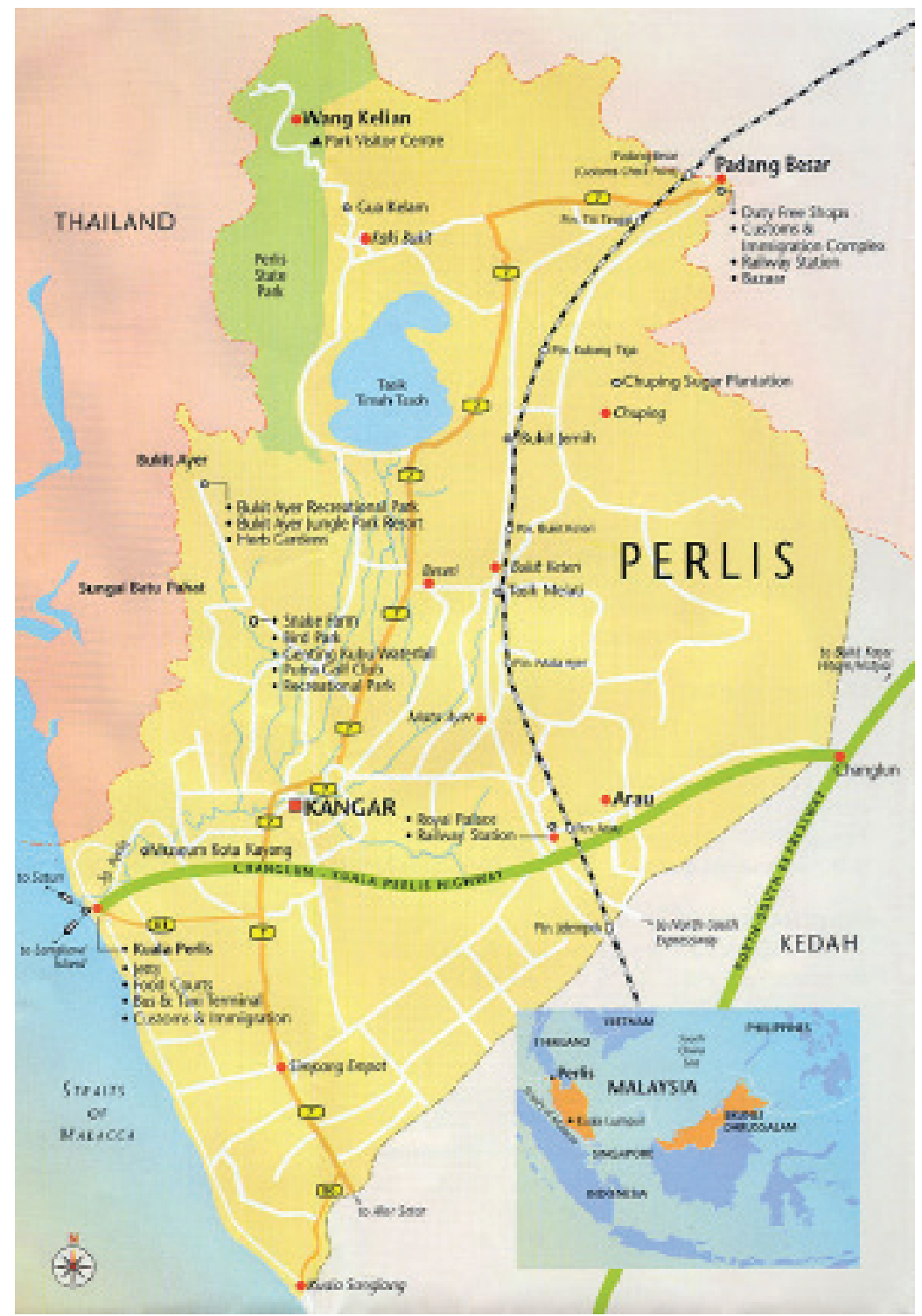

FIGURE 1. Location of the study area at Mata Ayer, Perlis 
(red color pin) at the middle and finally upstream pin at the bottom position. The wood sample taken using borer applied with Methyl Orange for $15 \mathrm{~min}$. After $15 \mathrm{~min}$, the length of bark and sapwood measured. The wood sample sent to the laboratory to measure its fresh and dried weight. The results from SFM were corrected with this information to determine the values of sap flow in the Sap flow tool lite software.

The sap flow was measured diurnally for 15 days at 30 min interval. Measurement was taken during August 2013. The average relative humidity ( $\mathrm{RH}$ ) during the observation was $86.24 \%$ with temperature of $25^{\circ} \mathrm{C}$ and vapor pressure deficit (VPD) of $0.44 \mathrm{kPa}$.

\section{RESULTS AND DISCUSSION}

\section{CLIMATE INFORMATION OF THE STUDY AREA}

The study area received a total of $590 \mathrm{~mm}$ rainfall (Figure 2) during the observation month that occurred within 13 days of the month with the average temperature of $25^{\circ} \mathrm{C}$. The highest rainfall was $180 \mathrm{~mm}$ day $^{-1}$ with the average of $17 \mathrm{~mm}_{\text {day }}{ }^{-1}$.

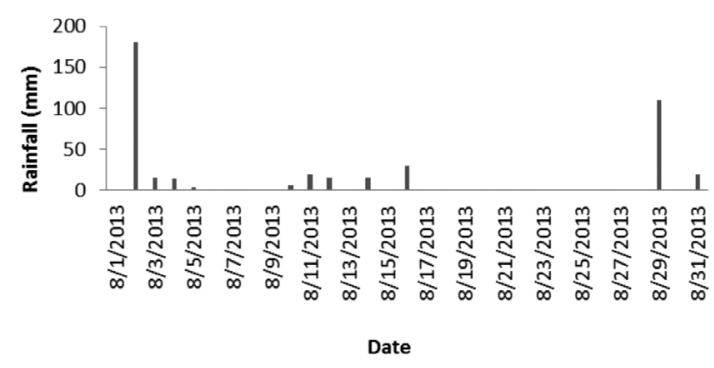

FIGURE 2. Rainfall at SPF Perlis during the observation period

Mean relative humidity of the area is $75 \%$ with maximum of $94 \%$ and minimum of $5 \%$. Vapor Pressure Deficit-VPD (Figure 3) was found to be negatively correlated to relative humidity-RH at the study site. This suggests that VPD is strongly influenced by the variations in RH. Highest VPD $(0.83 \mathrm{kPa})$ occurred at the lowest RH $(76 \%)$. However, VPD respond positively with temperature suggesting that increase in temperature will increase the VPD (Figure 4). In this case, VPD increase from 0.19 to 0.83 $\mathrm{kPa}$ when temperature increases at $3^{\circ} \mathrm{C}$.

\section{DAILY SAP VOLUME}

Daily observation shows that water flow in the tree is associated with rainfall. Flows are stable during antecedent rainfall but started to fluctuate after rainfall. This may be associated with the increase of available water in the soil. The daily flow for the bigger tree is very small and was not much affected by the rainfall event. The average water movement was $19 \mathrm{~L} \mathrm{day}^{-1}$ in small tree and only $0.13 \mathrm{~L}$ day $^{-1}$ in bigger tree. Water movement pattern of 16 and 38

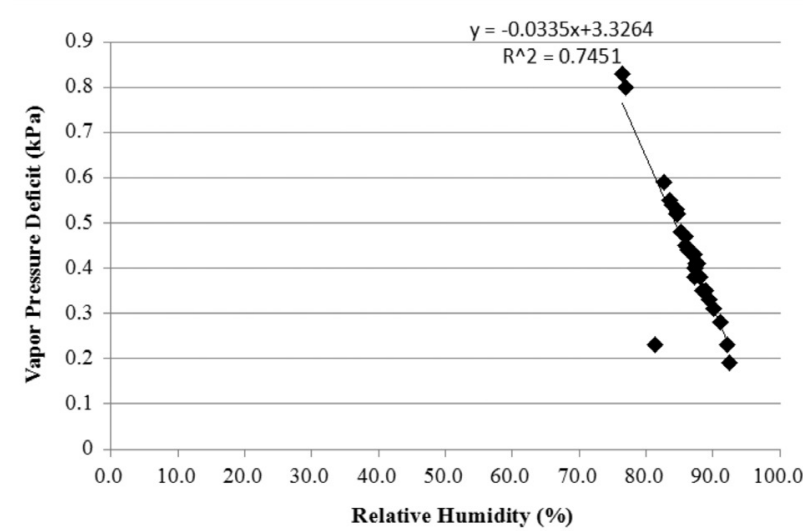

FIGURE 3. Vapor pressure deficit and relative humidity of the study area

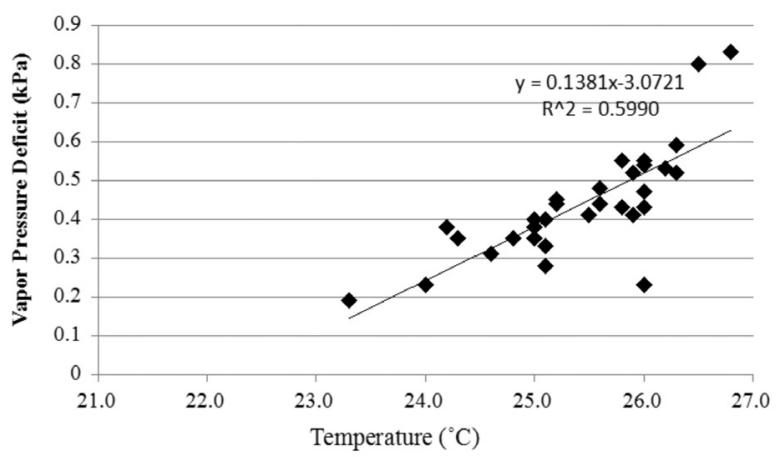

FIGURE 4. Vapor pressure deficit and temperature of the study area

$\mathrm{cm}$ Tectona grandis is similar but differ in the amount of water transported.

There is no significant relationship between sap volume and RH in 16 and $38 \mathrm{~cm}$ dbh (Figures 5 \& 6). Most of the sap volume occurred in $16 \mathrm{~cm}$ dbh within the RH range of 84 to $86 \%$ and 83 to $86 \%$ for $38 \mathrm{~cm} \mathrm{dbh}$. Water use distribution in small stem $(16 \mathrm{~cm}$ dbh) Tectona grandis occurred at 0.4 to $0.6 \mathrm{kPa}$ VPD with decreasing trend. This suggested that as the VPD increases, the plant transport less water from the root. Water use distribution in bigger stem $(38 \mathrm{~cm} \mathrm{dbh})$ Tectona grandis occurred at 0.4 to 0.6 $\mathrm{kPa}$ VPD with increasing trend. This shows that water movement volume in different diameter were influenced by the different in VPD. Higher VPD increases the transpiration demand, influencing how much moisture from plant tissues is transferred into the air through regulating leaf stomata opening. This suggests that as the VPD increases the plant draw more water from its roots.

\section{MEAN SAP VELOCITY}

Sap velocity changes was pronounce in smaller tree while more stable in a bigger tree. The presence of rainfall has no effects on the sap velocity in bigger tree. Mean sap velocity was increase at the rate of $3.6 \mathrm{~cm} \mathrm{hr}^{-1}$ within $5 \mathrm{~h}$ and drop slowly at the rate of $2.2 \mathrm{~cm} \mathrm{hr}^{-1}$ in smaller tree. The rate of mean velocity in bigger tree varies only between 


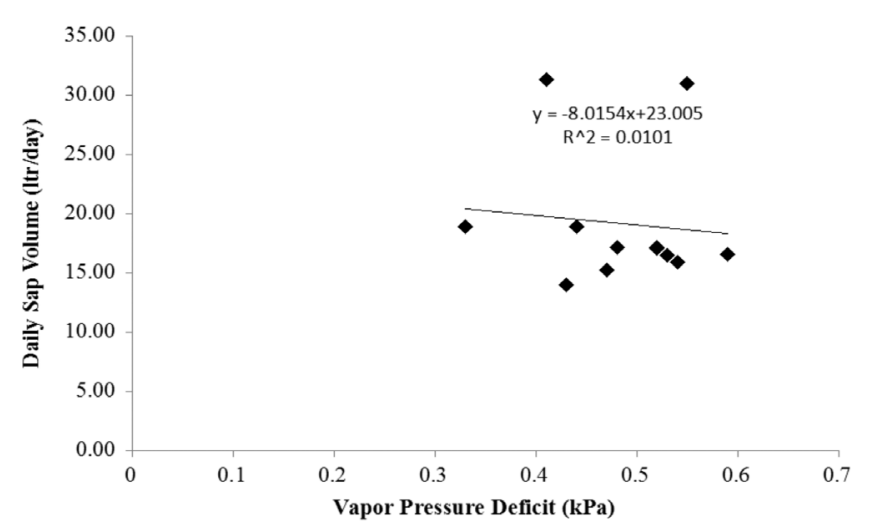

FIGURE 5. Mean daily sap volume and vapor pressure deficit in $16 \mathrm{~cm}$ dbh Tectona grandis

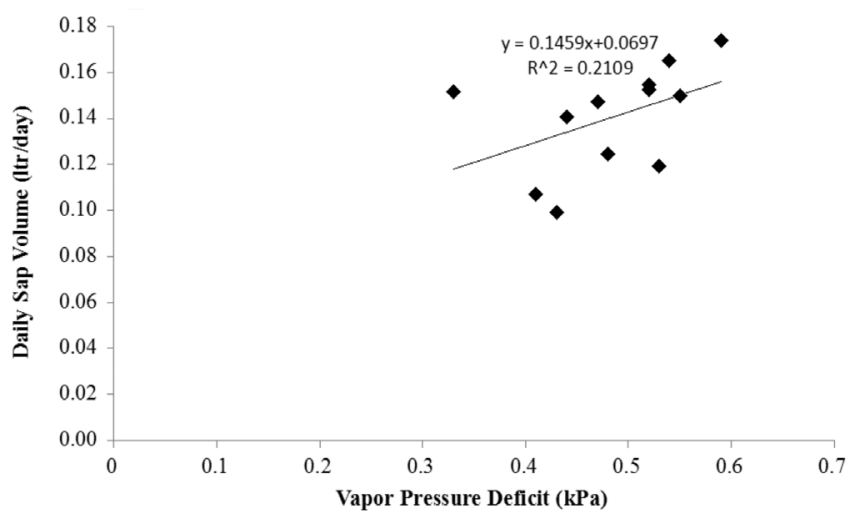

FIGURE 6. Mean daily sap volume and vapor pressure deficit in $38 \mathrm{~cm}$ dbh Tectona grandis

$0.8 \mathrm{~cm} \mathrm{hr}^{-1}$ during rising condition and drop at $0.6 \mathrm{~cm} \mathrm{hr}^{-1}$. The average velocity is $6.5 \mathrm{~cm} \mathrm{hr}^{-1}(16 \mathrm{~cm} \mathrm{dbh})$ and $2.3 \mathrm{~cm}$ $\mathrm{hr}^{-1}(38 \mathrm{~cm} \mathrm{dbh})$. The mean average velocity is $6.5 \mathrm{~cm} \mathrm{hr}^{-1}$ ( $16 \mathrm{~cm} \mathrm{dbh)} \mathrm{and} 2.3 \mathrm{~cm} \mathrm{hr}^{-1}(38 \mathrm{~cm} \mathrm{dbh})$ with the standard deviation of 6.8 for smaller tree and 4.7 for bigger tree.

The correlation coefficient between the mean sap velocity in both tree is $r=0.9$. This shows that the pattern of sap velocity in smaller and bigger trees is strongly correlated. The correlation is differing in their amount. This situation suspected due to the active growth in smaller tree compared to the bigger tree. It was also suspected that the bigger tree taking water from groundwater while smaller tree use only soil water. Therefore, the tension in bigger tree is high compared to small tree because it needs more energy to pull water from underground level. Whereas the smaller tree uses only water from the soil water which is nearer to the surface.

\section{DIURNAL VARIATION}

Diurnal variations (Figures $7 \& 8$ ) of sap flow in Tectona grandis shows that tree sizes influence the differences in sap velocity between outer and inner layer. Biggest tree perform high sap velocity at the inner layer within the sapwood compared to cambium or bark. The velocity differences between these layers are $1.1 \mathrm{~cm} \mathrm{hr}^{-1}$. Maximum sap velocity for bigger Tectona grandis is $11 \mathrm{~cm} \mathrm{hr}^{-1}$ for inner layer and
$6.6 \mathrm{~cm}^{-1}$ for outer layer. The range of sap velocity for inner layer is $14 \mathrm{~cm} \mathrm{hr}^{-1}$ while outer layer is $8.8 \mathrm{~cm} \mathrm{hr}^{-1}$. In smaller tree, sap velocities tend to be high at outer layer compared to inner layer. The differences between these layers are 30 $\mathrm{cm} \mathrm{hr} r^{-1}$ with maximum velocity is $33 \mathrm{~cm} \mathrm{hr}^{-1}$ in outer layer compared to $2.5 \mathrm{~cm} \mathrm{hr}^{-1}$ at the inner layer.

Sap velocity of the Tectona grandis is stable during night. It started to rise at 8.00 a.m when the sunshine appear and getting even higher at 9.00 a.m. to 5.00 p.m. The rising curve of the water use might also associate with the stomata opening in the leaves. The curves gradually decrease at 6.00 p.m onward. Sap velocity trend in the bigger tree is moving gradually between the inner and outer layer. However, in the smaller tree sap velocity move very fast at the outer layer and slower at the inner layer. This may be due to the proportion of sapwood in the smaller tree. This situation is expected to become stable when the tree is getting bigger.

\section{CONCLUSION}

Variations in sap flow of Tectona grandis characterized by several environmental and tree physiology factors. It was found that size does to contribute the difference in water use of the Tectona grandis. Small stem has active sap flow compared to bigger stem. High sap volume in small stem is suspected due to the rooting system where root withdraw water at soil layer while the bigger stem withdraw water 


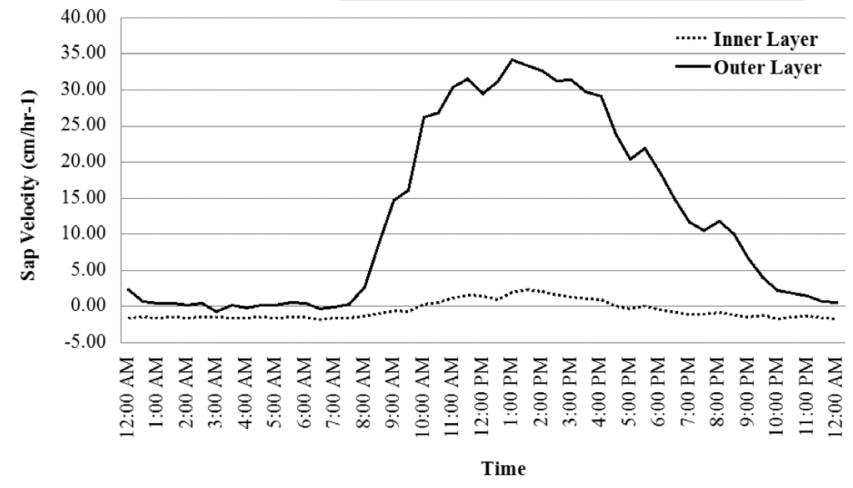

FIGURE 7. Diurnal sap velocity of the $16 \mathrm{~cm}$ DBH Tectona grandis

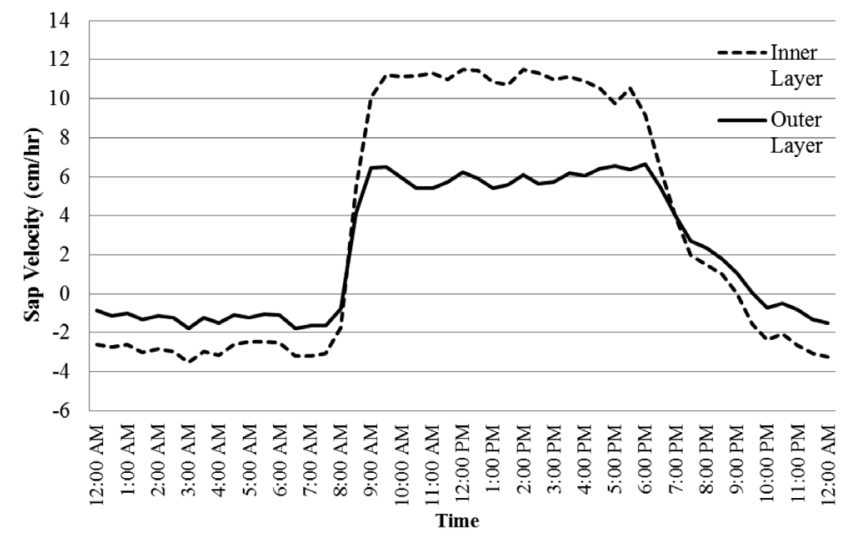

FIGURE 8. Diurnal sap velocity of the $38.5 \mathrm{~cm}$ DBH Tectona grandis

from ground water. Sap volume (total sap) and velocity is higher in $16 \mathrm{~cm}$ Tectona grandis compared to $38 \mathrm{~cm}$. Diurnal sap flow is active during the day time compared night time as a results of transpiration and photosynthesis in trees.

Information on tree sap movement is useful for water management in plantation scheme and in the selection of suitable species pertaining to the drainage conditions of an area. This information can be used in plantation forest activities to enhance yield. At the same time the information will also contribute to the management of water resources in the plantation landscape in maximizing yield and minimize operational cost.

\section{REFERENCES}

Cermak, J. \& Kucera, J. 1981. The compensation of natural temperature gradient at the measuring point during the sap flow determination in tree. Biologia Plantarum (Praha) 23: 469-471.

Cienciala, E., Kucera, J., Lindorth, A., Cermak, J., Grelle, A. \& Halldin, S. 1997. Canopy transpiration from a boreal forest in Sweden during a dry year. Agriculture Forest Meteorology 86: 157-167.

Diawara,A.,Loustau, D. \& Berbigier, P. 1991. Comparison of two methods for estimating the evaporation of a Pinus pinaster (Ait.) stand: Sap flow and energy balance with sensible heat flux measurements by an eddy covariance method. Agricultural and Forest Meteorology 54: 49-65.
Du, Z.C. \& Yang, Z.G. 1995. Comparative study on the characteristics of photosynthesis and transpiration in Aneurolepidium chinensis of different soil types. Acta Bot. Sin. 37(1): 66-73.

Lagergren, F. \& Lindorth, A. 2002. Transpiration response to soil moisture in pine and spruce trees in Sweden. Agriculture Forest Meteorology 112: 67-85.

Olbrich, B.W. 1991. The verification of the heat pulse velocity technique for estimating sap flow in Eucalyptus grandis. Canadian Journal of Forest Research 21: 836-841.

Scott D. F. 2005. On the hydrology of industrial timber plantations. Hydrological Processes 19(20): 4203-4206.

Smith, D.M \& Allen, S.J. 1996. Measurement of sap flow in plant stems. Journal of Experimental Botany 47(305): 1833-1488.

Nisbet, T. 2005. Water use by trees. Forestry Commission Information Note. ISSN 1460-3802. pp. 1-8.

Weibel, F.P. \& De Vos, J.A. 1994. Transpiration measurement on apple trees with an improved stem heat balance method. Plant and Soil 166: 203-219.

Forest Research Institute Malaysia (FRIM)

52109 Kepong, Selangor Darul Ehsan

Malaysia

*Corresponding author; email: marryanna@frim.gov.my

Received: 17 March 2015

Accepted: 21 June 2016 